\section{The peaceful resolution of U.S.-Mexican transboundary water disputes}

Alyssa M. Neir and Michael E. Campana

$\mathrm{T}$ ransboundary water along the U.S.-Mexican border is managed by bilateral agreements and institutions created by the United States and Mexico. These allocate water, protect the economic benefits derived from transboundary water resources, and provide an avenue for resolving disputes. Recent and ongoing controversies along the border demonstrate that even in the face of competing uses for scarce resources, the countries, their citizens, and interested stakeholders are employing these international tools to resolve disputes. Three examples of the peaceful resolution of water-related conflict involving the United States and Mexico are presented. The first and second regard, respectively, the United States' plan to line the All-American Canal (AAC) and Mexico's fulfillment of agreements to deliver Rio Grande water to Texas. The third case concerns the Hermosillo basin aquifer in the Mexican state of Sonora. Although it does not involve a transboundary water, this case is relevant because it illustrates how an international agreement - in this case, the North American Free Trade Agreement (NAFTA) - can affect water resources that lie wholly within one country.

The U.S- Mexican water-related institutional and legal framework

The United States and Mexico have a well-established framework for managing water that is based on international Treaties, Minutes, and Agreements. Treaties include the Treaty of 2 February 1848; the Convention of 29 July 1882; the Convention of 12 November 1884; the Convention of 1 March 1889; the Convention of 21 May 1906; the Convention of 1 February 1933; the Treaty for Utilization of Waters of the Colorado and Tijuana Rivers and of the Rio Grande in 1944 (1944 Water Treaty); the Chamizal Convention of 29 August 1963; and the Treaty of November $1970 .^{1}$ The International Boundary Commission was created in 1889 (and changed to its current name, the International Boundary and Water Commission, IBWC, in 1944) to deal specifically with boundary and water issues. ${ }^{2}$

Minutes, passed by the IBWC, provide an avenue for some degree of adaptive conflict management, allowing the parties to expand their interests in cooperative water resource management. An example is the common interest in groundwater resources and water quality which prompted this passage in Minute 242:

With the objective of avoiding future problems, the United States and Mexico shall consult with each other prior to undertaking any new development of either the surface [water] or the groundwater resources, or undertaking substantial modifications of present developments, in its own territory in the border area that might adversely affect the other country. ${ }^{3}$

The framework of Treaties, Minutes, and Agreements provides the foundation for water allocation, international boundary delineation, and cooperation. Similar types of bilateral agreements and institutions exist between the United States and Canada to manage transboundary water resources.

The North American Free Trade Agreement (NAFTA)

In 1994, the North American Free Trade Agreement (NAFTA) was adopted by Canada, Mexico, and the United States as a way of cooperating on trade issues. This agreement essentially removed tariffs to facilitate increased trading which would lead to greater economic opportunities for all countries involved. Water is governed by this agreement when it is considered to be an article of commerce.

The successful passage of the 1992 constitutional amendment that allowed for increased water privatization paved the way for Mexican participation in NAFTA, as it was necessary for the government to let the private sector have some sort of autonomy to stimulate investment. However, the citizenry is cautious about these moves because of real and potential abuse by private companies. If the government decides it would rather let the market operate in the realm of water supply, it must actively enforce its own regulations to the benefit of its citizenry and the environment. If the government looks the other way and allows abuses, such as those alleged by urban water customers, then it might cause conflict if it does not act to regulate overpumping of border aquifers and discharge of pollutants into streams and aquifers.

The balance among government, societal, and scientific elements is vital to the success of applying NAFT A to water resources. Due to NAFTA's economic emphasis and its potential to treat water as an article of commerce (water as an "economic good"), it would be easy to make decisions which do not include the scientific process and only address some of society's concerns. The presence of balanced governmentscience and science-society interfaces is necessary to restrain NAFTA's influence visà-vis water resources.

\section{Lining the All-American Canal}

The All-American Canal (AAC) parallels the U.S.-Mexican border, running from Imperial Dam to the Imperial Valley in California (Figure 1). ${ }^{4}$ The 82 -mile (132kilometer) canal, located entirely within the United States, is owned by the U.S Bureau of Reclamation (BOR) and has carried water from the Colorado River to California since the $1940 \mathrm{~s} .{ }^{5}$ The unlined canal delivers 3 million acre-feet (AF) (or 3,700 million cubic meters, MCM) of water each year. ${ }^{6}$ In 1988, Public Law 100-695 


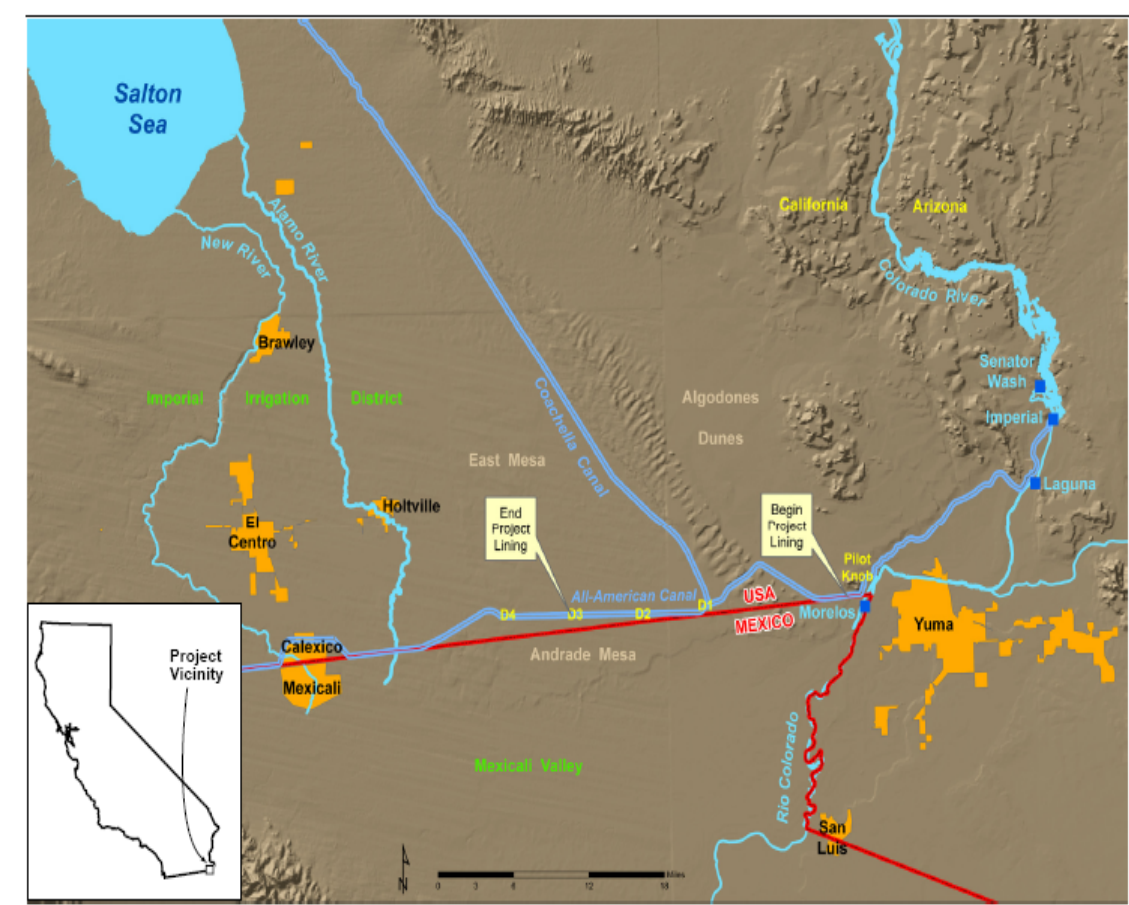

Figure 1: Location of the All-American Canal. Source: U.S. Bureau of Reclamation (BOR, 2006). Reprinted with permission.

was passed which gave BOR the authorization to line the All-American Canal. ${ }^{7}$ It has taken almost 20 years for the U.S. government to approve funding for the project and additional conveyance infrastructure. ${ }^{8}$

Controversy over the lining of the All-America Canal involves efficiency, economic, and environmental aspects. The United States is attempting to make the canal more efficient by reducing leakage and using the saved water to augment California's water supply. It has been estimated that 70,000 AF (86 MCM) per year could be added to California's water supply by lining the canal. ${ }^{9}$ However, the leaking water enters the groundwater system and flows across the border into Mexico, specifically the Mexicali valley area. ${ }^{10}$ The cities on the Mexican side of the border rely on the groundwater for domestic and agricultural uses that are the basis for the economy in that area. The groundwater on the Mexican side of the border also is of environmental importance as wetlands in the Andrade Mesa area provide habitat for migrating birds.

As stated, the United States intends to use the conserved water to supply cities in California. ${ }^{11}$ California is investing heavily in the project which will cost US $\$ 327$ million. ${ }^{12}$ However, due to decreased groundwater quality, the project will also have economic effects on Mexico. Specifically, an expected "increase in soluble salts will result in a loss of $9 \%$ of the area's production and an increase of $13 \%$ in energy costs, which in turn constitute $25 \%$ of the operational and maintenance costs of the hydroagricultural infrastructure of Irrigation District 014." 13

The groundwater flowing across the border also sustains critical wetland habitat, Andrade Mesa, in Mexico. ${ }^{14}$ The potential environmental impacts of the project were raised in a 2005 lawsuit by Mexico and by environmental groups from both sides of the border. ${ }^{15}$ The project's long history has resulted in an extensive list of different types of actions taken by the United States and by Mexico concerning the project.

The two countries have very different perspectives about who owns the water that is seeping from the canal. The United States claims that the seeping groundwater is part of its allocation under the 1944 Treaty. ${ }^{16}$ In contrast, Mexico argues that it has acquired the seepage rights through continuous use of the resource. ${ }^{17}$ Furthermore, Mexico uses Minute 242 which pertains to development by one country that may affect the water resources of the other country to support its argument. The difference of opinion lies in a national versus international perspective wherein the United States perceives the issue as national and Mexico as international.

The long history of the AAC project highlights specific characteristics of the countries' relationship concerning water resources. At the forefront of this relationship are the established international dispute resolution mechanisms that were developed through mutual agreement. International dispute resolution mechanisms that have been used in the AAC dispute include an informal protest through the IB WC (1998), an IBWC Discussion (2000), a letter, a discussion at other meetings (2005), a lawsuit (2005), and a stakeholder meeting. ${ }^{18}$ Litigation is another option for Mexico; however, engaging in a sharpened level of international dispute resolution may not always be in a country's best interest:

... a legal solution, much like the unilateral outcome itself, amounts to a zero-sum, loser pays, sub-optimal solution that entails high risks for both parties. While in a narrow technical sense justice might be done by litigating the dispute, a litigated outcome is hardly the best mechanism for advancing binational cooperation or achieving a management outcome consistent with the emerging norms of sustainable development of the region's water resources. ${ }^{19}$

It is clear by Mexico's limited actions throughout the history of the project that it is weighing the pros and cons of the situation; it wishes to preserve the amicable relation of the two countries and resolve the issue within the context of other binational water issues. Since neither country is consistently the downstream country, it is possible for the actions of either to negatively affect the other. This facilitates compromises and trade-offs. For example, Mexico raised its objections to the lining of the AAC when the United States raised the issue of Mexico's Rio Grande water deliveries to Texas: ${ }^{20}$ 
In 2005, at a trilateral meeting on security between the governments of the partner countries to the North American Free Trade Agreement, the Mexican government raised the issue of lining the AAC, but only after the government of Texas raised the issue of the historic water debt from the Rio Grande watershed. Since that meeting, both governments have been negotiating a solution to their differences over the AAC lining project. ${ }^{21}$

International transboundary issues are not isolated events in the international arena. The relative power of each country, the health of the relationship, and the relative importance of the dispute within the context of the broader national and international dialogue mean that each country will attempt to balance its interests. This balance may result in compromises or additional power that a country can use in other negotiations.

Mexico's Rio Grande water deliveries to Texas

The second case, that of Mexican water deliveries to Texas, demonstrates how the IBWC was used to resolve Mexico's Rio Grande water delivery deficit and also discusses potential NAFTA implications of that deficit.

The NAFTA implications of Mexico's Rio Grande (known in Mexico as the Rio Bravo) water deliveries to the United States are currently being explored and defined in a legal claim brought by irrigation districts, water right holders, and a water supply company under Chapter 11 , Articles 1102 and 1110 , of NAFTA. ${ }^{22}$ As stated in the 1944 Water Treaty, Mexico is obligated to deliver a certain quantity of Rio Grande water to the United States. Specifically:

One-third of the flow reaching the main channel of the Rio Grande (Rio Bravo) from the Conchos, San Diego, San Rodrigo, Escondido, and Salado Rivers and the Las Vacas Arroyo, provided that this third shall not be less, as an average amount in cycles of five consecutive years, than 350,000 acre-feet (432 MCM) annually. The United States shall not acquire any right by the use of the waters of the tributaries named in this subparagraph, in excess of the said 350,000 acre-feet (432 MCM) annually, except the right to use one-third of the flow reaching the Rio Grande (Rio Bravo) from said tributaries, although such one-third may be in excess of that amount. ${ }^{23}$

The deliveries are based on five year cycles; however, the Treaty also provides for a contingency plan when Mexico is unable to deliver the required amount:

In the event of extraordinary drought or serious accident to the hydraulic systems on the measured Mexican tributaries, making it difficult for Mexico to make available the run-off of 350,000 acre-feet (432 MCM) annually, allotted in subparagraph (c) of paragraph B of this Article to the United States as the minimum contribution from the aforesaid Mexican tributaries, any deficiencies existing at the end of the aforesaid five-year cycle shall be made up in the following five-year cycle with water from the said measured tributaries. ${ }^{24}$

Mexico experienced a drought during the 1992-2002 period, which resulted in a water delivery deficit of more than 1.5 million AF (1,850 MCM) by 2002, 1.024 million AF (1,263 MCM) of which accrued during the 1992-1997 five-year cycle. ${ }^{25}$ Discussions between the Mexican Section of the IB W C and Mexico's National W ater Commission began in 1998 to determine how Mexico would repay the water debt. ${ }^{26}$ These talks intensified in 1999, and in 2000 Mexico repaid a portion of the debt. ${ }^{27}$

In 2001, the IB WC led government-to-government negotiations. These culminated in the passage of Minute $307 .{ }^{28}$ Minute 307 covered $600,000 \mathrm{AF}$ (740 MCM) of the deficit and provided for continued discussions to completely resolve Mexico's deficit Furthermore, the Minute demonstrated the desire of the two countries to reach a satisfactory conclusion:

That the Government of the United States and the Government of Mexico, animated by the spirit of friendship that prevails in the relationship between the two countries and committed to prevent recurrence like the situation considered here will work jointly to identify measures of cooperation on drought management and sustainable management of this basin.

Discussions and negotiations continued into 2002 and another Minute, Minute 308, was signed wherein the two countries agreed to continue their negotiations. In 2005, the two countries finally "... reached an understanding that [would] effectively eliminate Mexico's Rio Grande water debt by September 30, 2005."29 This plan involved water transfers and additional water deliveries by Mexico.

This case shows how the two countries used their dispute resolution mechanism - the IBWC - as outlined in the 1944 Water Treaty (Section I, Article 2) to satisfactorily resolve the issue of Mexico's Rio Grande water debt incurred during the 1992-2002 drought. As reported by the IBWC:

Based on implementation of the understandings reached, the United States and Mexico will consider that Mexico's water debt is completely eliminated. Under the $1944 \mathrm{~W}$ ater Treaty, Mexico is to deliver to the United States an annual average of 350,000 acre-feet [ $432 \mathrm{MCM}$ ] in the Rio Grande basin in cycles of five years. Since 1992, Mexico has accumulated a water deficit, which reached a high of more than 1.5 million acre-feet $[1,850 \mathrm{MCM}]$ in $2002 .^{30}$

However, a claim was filed under NAFTA that explores whether NAFTA extends to economic losses during the time that the water deficit was still outstanding (2002- 
2005), and the two countries were negotiating to resolve the issue. This suit was brought by water right holders in Texas.

The claim was filed by irrigation districts, water right holders, and a water supply company in Texas (claimants) in 2004. The claimants are suing Mexico for the fair market value of 1,013,056 acre-feet (1,250 MCM) of water. The Texans argue that Mexico's deficient delivery of 1,476,181 acre-feet (1,821 MCM) of Rio Grande water from 1992-2002 under the 1944 Water Treaty deprived them of an estimated US\$1 billion from decreased business activity. ${ }^{31}$

The intent of our article is not to discuss the merits of the claimants or of Mexico's arguments, but to highlight that the existing system is being used to manage conflict. The opportunity for legal recourse allows the Texans to resolve their dispute with Mexico peacefully and without resorting to violence or aggressive actions to obtain the disputed water. In addition, this case suggests that there may be potential NAFT A implications from existing water allocation treaties. The outcome of this pending litigation may have significant implications that may create a broad applicability of NAFTA that could include treaties. This may mean that a country may be required to compensate water right holders when it fails to deliver a required amount of water. In effect, this would attach a monetary value to the water allocated to each country.

\section{The Hermosillo basin}

The Hermosillo basin aquifer is located in the Mexican state of Sonora (Figure 2). While the aquifer does not straddle the U.S.-Mexican border, a NAFTA-linked spillover effect exists. The basin's use for agricultural production as a result of NAFTA has caused local conflict due to competing demands. This region typically grew crops for local consumption. But after the removal of trade barriers, many higher valued fruits and vegetables replaced these traditional crops and are primarily shipped to the United States for consumption. The change in what was produced led to the consolidation of many farms in the region with larger farms controlling most of the acreage. The resulting shift in agricultural production has placed a strain on the coastal aquifer with sea-water intrusion threatening many wellfields. ${ }^{32}$ At the same time, the municipal government has decided to expand its industrial sector and needs water to do so. The government proposed pumping salt-water from coastal wells and desalting the water; however, this has created tension with the growers who hold the current monopoly over the coastal aquifer.

This case reveals relationships among government, science, and society, and how the eventual decision will affect the different areas. This tension, a partial outcome of trade between the two countries, leaves the aquifer vulnerable to over-exploitation and is a direct result of economic growth in the Hermosillo basin. Any expansion can further reduce groundwater quality by drawing in more seawater. The government will have to decide if the value of new industry outweighs existing agricultural exports, and it may be that a switch to a different industry has a positive effect on the

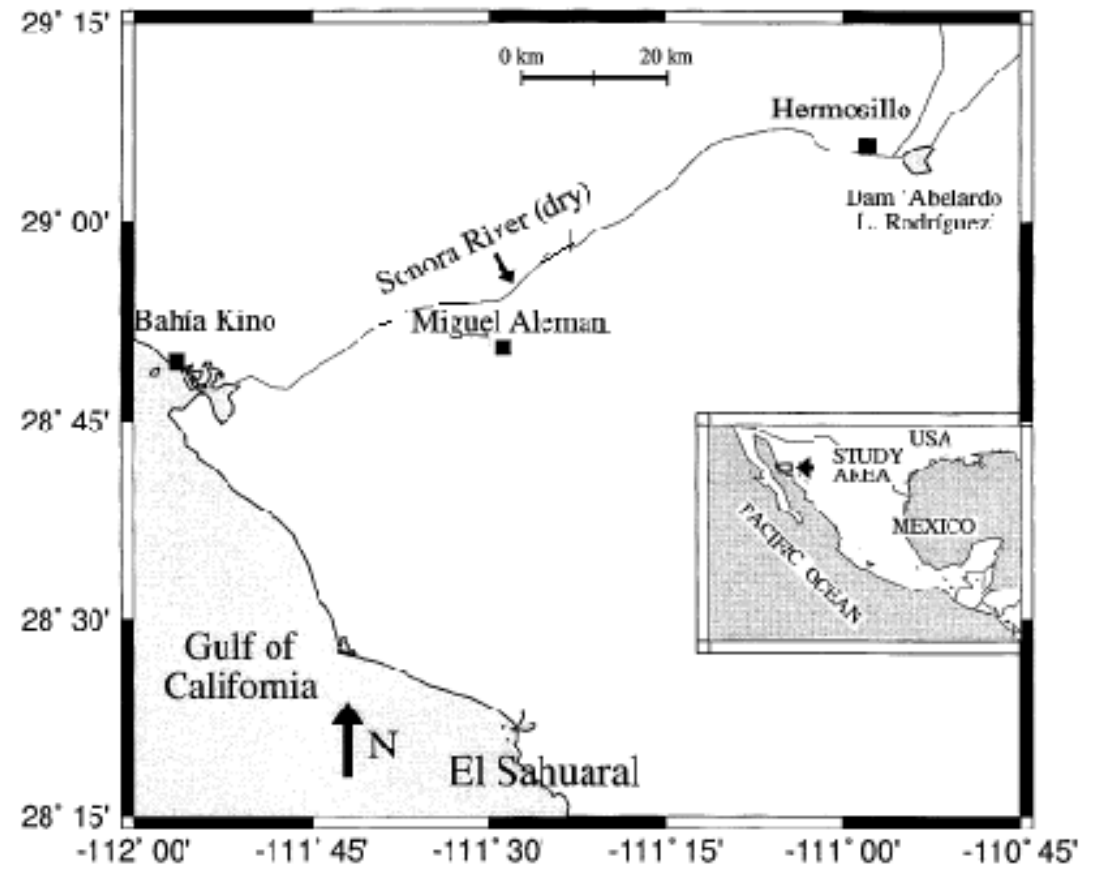

Figure 2: Map of the Hermosillo basin. Source: Steinich, et al., 1998. Reprinted with permission.

aquifer but might bring in less money to the region. The government knows the scientific and potential societal impacts of its decisions and must determine how to manage the aquifer in a "sustainable" manner so that the entire region does not suffer.

Summary

The United States and Mexico have developed a solid framework to manage transboundary surface and groundwater resources and associated conflicts over the past 100 years. Each dispute in this long history of conflicts or disagreements provides the foundation for resolving similar disputes in the future. As demonstrated by the passage of Minutes, cooperation between the United States and Mexico changes and adapts to new issues. The international institutions are based on cooperation by both countries. If they choose not to use or abide by the agreements and decisions, then the viability of peaceful resolution diminishes. But as demonstrated by the examples of the AAC lining and 1944 Water Treaty deliveries, the two countries, and even the citizens, are choosing to use the tools available to them to resolve conflicts peacefully. 
One of the most complicated issues that can affect the quality and use of transboundary waters is the implementation of NAFTA. This has added another layer to the agreements already established between the countries. NAFTA's power has the potential to create an unbalanced government-society interface and severely limit scientific involvement. The interface has the potential to be unbalanced because NAFTA only recognizes economic uses of water and disregards its environmental and/or ecological uses. This focus on narrowly-understood economics also has the potential to limit the scientific process by acknowledging water-related science only when a monetized value can be attached to water, a disturbing prospect. NAFTA may also influence water issues within a country, even when the water resource is not transboundary. In one instance, a Mexican aquifer in the Hermosillo basin has been heavily stressed because the removal of trade tariffs for certain high-valued fruits and vegetables traded to the United States and has caused changes in water and land use.

\section{Conclusion}

The adaptability of the IB WC and its ability to resolve bilateral disputes and promote cooperation between the countries is demonstrated in the examples of conflict and cooperation. Cooperation is demonstrated by the voluntary use of the institutional entities available to each country such that effective management of transboundary water resources is accomplished. The IBWC, while not specifically established to consider groundwater, has managed to function properly whenever groundwater is an issue, thus affecting transboundary groundwater management, if only on an ad hoc basis. The unknown factor is NAFTA, whose treatment of water as an economic good may trump other uses and existing agreements and may lead to payments for damages suffered. Time will tell how NAFTA will affect water disputes, but both countries should exercise caution to ensure NAFTA does not supercede all other considerations.

There is no predetermined process that clearly treats transboundary groundwater; both the United States and Mexico should modify existing agreements so that groundwater is specifically included. In light of increasing pressures on the water resources of both countries, this modification is essential and long overdue.

\section{Notes}

Alyssa M. Neir is an environmental planner at Golder Associates, Inc., in Redmond, Washington, USA. She is a graduate of the University of Pennsylvania and has a Master of Water Resources degree from the University of New Mexico. She can be reached at aneir@golder.com. Michael E. Campana is the director of the Institute for Water and Watersheds and Professor of Geosciences, both at Oregon State University in Corvallis, Oregon, USA. A PhD in hydrology with a mathematics minor from the University of Arizona, he has 35 years of experience with western U.S. and international water management issues. He is also the founder and president of the
Ann Campana Judge Foundation (www.acjfoundation.org), a U.S. charitable foundation devoted to water and sanitation issues in developing countries. The corresponding author, he can be reached at aquadoc@oregonstate.edu. This article is a contribution of the Universities Partnership for Transboundary Waters (waterpartners.geo.orst.edu).

1. IBWC (2007b). IBWC is the International Boundary and Water Commission.

\section{2. $\operatorname{IBWC}(2007 \mathrm{a})$.}

\section{IBWC (1973).}

4. Zamora Arroyo, et al. (2006).

5. Zamora Arroyo, et al. (2006); Herrera Barrientos, et al. (2006).

6. Zamora Arroyo, et al. (2006)

7. Zamora Arroyo, et al. (2006)

8. Sánchez Munguía (2006a).

9. Zamora Arroyo, et al. (2006).

10. Herrera Barrientos, et al. (2006).

11. García Acevedo (2006).

12. García Acevedo (2006).

13. García Saille, et al. (2006, p. 96).

14. Zamora Arroyo, et al. (2006).

15. Zamora Arroyo, et al. (2006).

16. Mumme and Lybecker (2006); Sánchez Munguía (2006b).

17. Sánchez Munguía (2006b).

18. Mumme and Lybecker (2006); Medina Robles (2006); García Acevedo (2006); Zamora Arroyo, et al. (2006); Sánchez Munguía (2006a); Sánchez Munguía (2006b). 
19. Mumme and Lybecker (2006, p. 186).

20. Sánchez Munguía (2006a).

21. Sánchez Munguía (2006a, p. xxi).

22. Notice of Intent (2004).

23. Section II, Article 4(B)(c).

24. Section II, Article 4.

25. IBWC (2005); IBWC (1999).

26. IBWC (1998).

27. IBWC (2005); IBWC (1999).

28. IBWC (2001).

29. IBWC (2005).

30. IBWC (2005).

31. Notice of Intent (2004).

32. Rodriguez (2002); Steinich, et al. (1998).

\section{References}

[BOR] U.S. Bureau of Reclamation. 2006. “All-American Canal Lining Project Supplemental Information Report.” 12 January 2006.

[http://www.usbr.gov/lc/region/programs/AAC/SIR_1-12-06.pdf]

Carroll, J.E. 1983. Environmental Diplomacy: An Examination and a Prospective of Canadian-U.S. Transboundary Environmental Relations. Ann Arbor, MIC: The University of Michigan Press.

Carroll, J.E.1986. "Water Resources Management as an Issue in Environmental Diplomacy." Natural Resources Journal Vol. 26, No. 2, pp. 206-220.

de la Parra Rentería, C. A. 2006. "Forword,” pp. 59-76 in V. Sánchez Munguía, ed. The U.S.-Mexican Border Environment: Lining The All-American Canal: Competition or Cooperation for the Water in the U.S.-Mexican Border? San Diego, CA: San Diego State University Press, Southwest Consortium for
Environmental Research and Policy (SCERP), El Colegio de la Frontera Norte (COLEF).

García Acevedo, M.R.. 2006. "Looking Across the Canal: Reflections on Visions and Policies on Water Issues in the United States," pp. 129-154 in V. Sánchez Munguía, ed. The U.S.-Mexican Border Environment: Lining The All-American Canal: Competition or Cooperation for the Water in the U.S.-Mexican Border? San Diego, CA: San Diego State University Press, Southwest Consortium for Environmental Research and Policy (SCERP), El Colegio de la Frontera Norte (COLEF).

García Saille, G., Á. López López, and J.A. Navarro Urbina. 2006. "Lining the AllAmerican Canal: Its Impact on Aquifer W ater Quality and Crop Yield in Mexicali Valley," pp. 77-100 in V. Sánchez Munguía, ed. The U.S.-Mexican Border Environment: Lining The All-American Canal: Competition or Cooperation for the Water in the U.S.-Mexican Border? San Diego, CA: San Diego State University Press, Southwest Consortium for Environmental Research and Policy (SCERP), El Colegio de la Frontera Norte (COLEF).

Herrera Barrientos, J., M. Norzagaray Campos, G. García Saillé, A.A. Cortez Lara, and D. Jorquera Flores. 2006. "Fluctuations in Quality and Levels of Groundwater Near the Mexican-Proximate Portion of the All-American Canal," pp.59-76 in V. Sánchez Munguía, ed. The U.S.-Mexican Border Environment: Lining The AllAmerican Canal: Competition or Cooperation for the Water in the U.S.-Mexican Border? San Diego, CA: San Diego State University Press, Southwest Consortium for Environmental Research and Policy (SCERP), El Colegio de la Frontera Norte (COLEF).

[IBWC] International Boundary and Water Commission. 1973. "Minute 242." http://www.ibwc.state.gov/Files/Minutes/Min242.pdf[accessed 5 February 2007].

[IBWC] International Boundary and Water Commission. 1999. "International Boundary and Water Commission 1999 Annual Report." http://www.ibwc.state.gov/Files/Rpt1999E.PDF [accessed 12 February 2007].

[IBWC] International Boundary and Water Commission. 2000. "International Boundary and Water Commission 2000 Annual Report." http://www.ibwc.state.gov/Files/Rpt2000E.PDF [accessed 12 February 2007].

[IBWC] International Boundary and Water Commission. 2001. "International Boundary and Water Commission 2001 Annual Report." http://www.ibwc.state.gov/Files/Rpt2001E.PDF [accessed 12 February 2007].

[IBWC] International Boundary and Water Commission. 2002. "International Boundary and Water Commision 2001 Annual Report." http://www.ibwc.state.gov/Files/Rpt2002E.PDF [accessed 12 February 2007].

[IBWC] International Boundary and Water Commission. 2005. "The Boundary Marker." Spring 2005. http://www.ibwc.state.gov/Spring05Newsletter.pdf [accessed 12 February 2007].

[IBWC] International Boundary and W ater Commission. 2007a. "The International 
Boundary and Water Commission, Its Mission, Organization and Procedures for Solution of Boundary and Water Problems." http://www.ibwc.state.gov/html/about_us.html [accessed 5 February 2007].

[IBW C] International Boundary and Water Commission. 2007b. "The Boundary and Water Treaties." http://www.ibwc.state.gov/html/treaties.html [accessed 5 February 2007].

Medina Robles, F.A. 2006. "The Colorado River and the All-American Canal: The Historical and Cultural Perspective of Water in the U.S. Southwest," pp. 101-128 in V. Sánchez Munguía, ed. The U.S.-Mexican Border Environment: Lining The All-American Canal: Competition or Cooperation for the Water in the U.S.Mexican Border? San Diego, CA: San Diego State University Press, Southwest Consortium for Environmental Research and Policy (SCERP), El Colegio de la Frontera Norte (COLEF).

Mumme, S.P. and D. Lybecker. 2006. "The All-American Canal: Perspectives on the Possibility of Reaching a Bilateral Agreement,” pp. 175-198 in V. Sánchez Munguía, ed. The U.S.-Mexican Border Environment: Lining The All-American Canal: Competition or Cooperation for the Water in the U.S.-Mexican Border? San Diego, CA: San Diego State University Press, Southwest Consortium for Environmental Research and Policy (SCERP), El Colegio de la Frontera Norte (COLEF).

Notice of Intent to Submit a Claim to Arbitration Under Section B, Chapter 11 of the North American Free Trade Agreement (Notice of Intent). 2004. To: Sr. Gregorio Canales, Director, Dirección General de Inversión Extranjera, Secretaría de Economía. 27 August 2004.

Rodriguez, J.M.M. 2002. “Aquifers and Free Trade; A Hermosillo Coast Case Study”. Red Fronteriza de Salud y Ambiente, A. C. and Texas Center for Policy Studies http://www.texascenter.org/publications/sonora-english.pdf [accessed 16 April 2007].

Sánchez Munguía, V. 2006a. "Introduction,” pp. xix-xxvi in V. Sánchez Munguía, ed. The U.S.-Mexican Border Environment: Lining The All-American Canal: Competition or Cooperation for the Water in the U.S.-Mexican Border? San Diego, CA: San Diego State University Press, Southwest Consortium for Environmental Research and Policy (SCERP), El Colegio de la Frontera Norte (COLEF).

Sánchez Munguía, V. 2006b. "Context and Implications for Resolving a Complex Binational Issue: Lining the All-American Canal,” pp. 213-230 in V. Sánchez Munguía, ed. The U.S.-Mexican Border Environment: Lining The All-American Canal: Competition or Cooperation for the Water in the U.S.-Mexican Border? San Diego, CA: San Diego State University Press, Southwest Consortium for Environmental Research and Policy (SCERP), El Colegio de la Frontera Norte (COLEF).

Steinich B., O. Escolero, and L.E. Marín. 1998. "Salt-water Intrusion and Nitrate
Contamination in the Valley of Hermosillo and E1 Sahuaral Coastal Aquifers, Sonora, Mexico." Hydrogeology Journal, Vol. 6, No. 4, pp. 518-526.

Zamora Arroyo, F., P. Culp, and O. Hinojosa Huerta. 2006. "Looking Beyond the Border: Environmental Consequences of the All-American Canal Project in Mexico and Potential Binational Solutions,” pp. 21-58 in V. Sánchez Munguía, ed. The U.S.-Mexican Border Environment: Lining The All-American Canal: Competition or Cooperation for the Water in the U.S.-Mexican Border? San Diego, CA: San Diego State University Press, Southwest Consortium for Environmental Research and Policy (SCERP), El Colegio de la Frontera Norte (COLEF). 